\title{
Lessons from the Kokugo (National Language) Readers
}

\author{
ELAINE GERBERT
}

Kokusaika, or "internationalization," has been one of the most frequently used words in the Japanese media since the early eighties. Japan's increasingly active presence in the world economy has given rise to an active debate over the ways in which the citizenry of Japan will function as participants on an international stage in the twenty-first century. In Japan, as in other countries, awareness of the growing importance of international relations in national life has refocused attention on education. Official initiatives to meet the challenge began in August 1984 when Yasuhiro Nakasone, the prime minister at the time, established an ad hoc Council on Educational Reform to review existing educational practices and make recommendations for their reform. ${ }^{1}$ Since then, efforts to enhance internationalization have focused largely on absorbing the increase in the numbers of foreign students, mostly from Asia, studying in Japan; providing for the education of Japanese children living overseas; instituting study abroad for upper secondary school students; and improving communication skills in foreign languages, primarily English. ${ }^{2}$

Thanks are due to Patricia Weiss for enabling me to share my thoughts on Japanese textbooks with the participants of two Mid America Japan in the Schools Seminars, and to Margaret Childs and the anonymous Comparative Education Review referees for reading and commenting on earlier versions of this article. I would also like to express appreciation to Vickie Doll, Endō Kenji, Joan LaValle, Rieko Nagamasa, Nobuko Narita, and Yagawa Sumiko for helping me to secure needed materials.

${ }^{1}$ Government of Japan, Ministry of Education, Mombushō 1990 Ministry of Education, Science and Culture (Tokyo: Ministry of Education Science and Culture Publications, 1990), p. 56. The council, consisting of forty-five representatives from elementary, secondary, and higher education, business, industry, and organized labor identified eight issues of pressing concern. Three of these were "basic requirements for an education relevant to the 21 st century," "coping with internationalization" and "coping with various changes in our society, including internationalization in different sectors," and the promotion of wider and more efficient use of the information media.

${ }^{2}$ Ibid., pp. 58-59. These efforts have been made under the auspices of the Mombushō (Ministry of Education) Headquarters for the Implementation of Educational Reform, a group organized for the purpose of executing recommendations made by the Council of Educational Reform and headed by the minister of education himself. In the newly revised course of study issued by the Mombushō in March 1989, kokusaika appears alongside koseika (individualization) and $j \bar{o} h \bar{o} k a$ (informationization) as a national educational goal. Koseika implies the promotion, not of individualism, as the term may imply, but of structural reorganization of university programs for the purpose of promoting greater flexibility and creativity, particularly in the area of scientific research. Jōhoka, undertaken to better cope with the "information age," calls for the infusion of more computers and other information technology into technical high school and university programs and more training for teachers in information science and technology. For information on research on the incorporation of kokusaika,

Comparative Education Review, vol. 37, no. 2.

(C) 1993 by the Comparative and International Education Society. All rights reserved.

0010-4086/93/3702-0004\$01.00 
At the same time that the government encourages "internationalization," elementary school readers, written and produced under the guidance of the Mombushō (Ministry of Culture), reinforce a sense of national identity. The culturally coded images and themes in these readers create an image of a world that is immediately and unmistakably "Japanese." While social studies textbooks teach young Japanese about the world, Japanese language readers preserve a core of native values and perspectives that serve to anchor the child in the world.

At the other end of the spectrum from the monocultural Japanese reader stands the multicultural American elementary school reader. This reader, often regarded as a model of cultural tolerance, focuses heavily on the varied ethnic and racial backgrounds of young people in the United States and, one may assume, in doing so, prepares young Americans to feel at home in a world made up of diverse others. In addition to stories featuring American children from different cultural backgrounds, there are many stories based on folktales from around the world (especially Africa) and stories about young people in different national settings. So varied are the characters and experiences depicted in these textbooks that one is often left wondering what nation their audiences might be living in. Cultural diversity, so absent in the Japanese reader, is everywhere present in the American reader. By contrasting the Japanese textbooks with American textbooks, I hope to show how Japanese materials are designed to create a common singular consciousness in their youth.

Fostering a sense of belonging to the Japanese nation through the readers is in keeping with the tenor of a 1984 address to the Council of Educational Reform by Prime Minister Nakasone, who said that educational reforms are to be guided by the principle of preserving and further developing traditional Japanese culture while at the same time cultivating in children universally accepted "moral and behavioral standards" for the purpose of enabling future Japanese citizens to "contribute to the international community with a Japanese consciousness." 3 That Japanese language readers should play a critical role in shaping the self-image of the Japanese is not surprising when one considers the ways in which the Japanese language has been viewed by many in Japan. There is a huge body of literature in

\footnotetext{
$k o s e i k a$, and $\bar{j} \bar{o} h \bar{o} k a$ into the curriculum, see Nihon Kyōiku Nenkan Kankō Iinkai ( Japanese Education Yearbook Publication Committee), Nihon kyöiku nenkan (Japanese education yearbook) (Tokyo: Gyōsei, 1991), p. 167.

${ }^{3}$ Italics are mine. See Robert Leestma, ed., Japanese Education Today (Washington, D.C.: U.S. Department of Education, 1987), p. 64. This position was also articulated in the Mombushō's newly revised 1989 course of study, where one of four recommendations reads: "To put more value on developing in children an attitude of respecting Japanese culture and traditions, as well as an increased understanding of the cultures and histories of other countries in the world. Thus children should be helped to develop the qualities required of a Japanese living in the international community" (Government of Japan, Ministry of Education, p. 24).
} 
the country that claims the essence of being Japanese to be inextricably linked to speaking the Japanese language and asserts the uniqueness of both the Japanese identity and the Japanese language. ${ }^{4}$

This study explores some of the ways in which readers in the past 8 years have fostered the sense of a "Japanese consciousness" in children who will reach adulthood around the year 2000. Citations and examples are taken from readers published by leading textbook publishing companies between 1984 and 1992 for grades $1-6 .{ }^{5}$

\section{The National Language and the National Language Reader}

The study of the Japanese language in the Japanese educational system is known as kokugo, the "national language." The word used to designate the Japanese language when it is studied as a foreign language by a nonnative Japanese, or when the Japanese language is distinguished from other languages in the world, is nihongo. One might say that nihongo is comparable to the face Japanese show to the outside (soto), while kokugo is comparable to the face reserved for the members of one's ingroup (uchi).

Kokugo study occupies more classroom time than any other subject in the 9 years of compulsory education: an average of 1,987 classroom hours are spent studying kokugo in grades 1-9, as opposed to 1,496 spent on mathematics, 943 on social studies, and 908 on science. ${ }^{6}$ In defining educational standards and procedures to be followed in the study of kokugo, the Mombushō prescribes a specific list of Chinese characters (kanji) to be learned at each grade level of compulsory education and the proper stroke order to be followed in writing each of about 2,000 characters. In elementary school, in addition to 996 characters, students must learn two phonetic syllabaries and the roman alphabet. Hiragana (the cursive phonetic syllabary consisting of 46 signs), is introduced in volume 1 of the two-volume first-grade reader. Katakana (the 46-letter angular phonetic

\footnotetext{
${ }^{4}$ The semimystical attitude toward the special nature of the Japanese language propounded in nihonjinron writing (literature that explores and asserts the "unique" character of the Japanese people) is by no means a recent phenomenon. Nationalist scholars of the seventeenth century, for example, undertook painstaking philological analysis of the Japanese language in order to support their claims of Japan's uniqueness. See Yamazaki Ansai, "Lectures concerning the Chapters on the Divine Age," in Sources of Japanese Tradition, trans. and ed. Ryūsaku Tsunoda, W. Theodore de Bary, and Donald Keene (New York: Columbia University Press, 1958), 1:358-60. More recent assertions of the inseparability of "Japaneseness" and the Japanese language have led the American linguist Roy Andrew Miller to comment that "the Japanese language has gradually been elevated to the position of one of the major ideological forces sustaining Japanese society, at the same time that it helps that society to close its ranks against all possible intrusions by outsiders" (Roy Andrew Miller, Japan's Modern Myth: The Japanese Language and Beyond [New York and Tokyo: Weatherhill, 1982], p. 283).

5 The readers surveyed in this study were published by Mitsumura Tosho Shuppan, the leading publisher of kokugo textbooks in Japan. I also discuss stories in readers published by Kyōiku Shuppan, Nihon Kyōiku, Nihon Shoseki, and Gakkō Tosho.

${ }^{6}$ Hitoshi Kaneko et al., Kyōiku Shōroppō (Guidelines for education) (Tokyo: Gakuyō Shobō, 1984), pp. 96-97.
} 
syllabary used to transcribe non-Sinitic foreign loanwords and onomatopoeia) is introduced in volume 2 . The study of romaji (roman letters) begins in the fourth grade.

The use of katakana to transcribe words borrowed primarily from Western languages (mostly English) suggests the strength of the outside (soto)/inside (uchi) dichotomy that underlies virtually all social transactions and speech forms in Japan. Transcription in katakana (as opposed to kanji, used to write words of Sinitic origin, or a combination of kanji and hiragana, used for words of Japanese origin) marks as different (alien) even words of Western origin that have been in use since the sixteenth century. A quick glance immediately determines the "foreign" provenance of a loanword. Of the thousands of European loanwords taken into the language, virtually none have made it to native status - that is, none are written in hiragana. This is comparable to a situation in which Americans would write "hurricane," "igloo," "croissant," and thousands of other words in upper-case letters to show that they are not original English words. The distinction between the Japanese language and foreign linguistic elements enters the consciousness of Japanese children from grade 1.

Six years of kokugo education in elementary school are followed by 3 years of kokugo classes in junior high school and another 3 years of kokugo study in senior high school. Junior high school students learn an additional 300,350 , and 252 characters in the 3 years of study, respectively. Senior high school students concentrate on reading modern and classical Japanese literature in their classes of Kokugo I, Kokugo II, Kokugo hyōgen ("national language expressions," basically a course in composition), Gendaibun (modern literature), and Koten (an introduction to classical Japanese grammar and literature and to kambun - a Japanese system of glossing classical Chinese texts). ${ }^{7}$ Elementary school kokugo texts may be said to develop "Japanese" attitudes toward self-expression, nature, the self in relation to nature and to others, and the past-in other words, to lay the psychological foundation on which the appeal of the literary canon introduced at the higher grade levels will rest.

Six commercial publishing companies produce textbooks for the elementary school system, in contrast to the situation in the United States, where over 100 companies engage in publishing elementary school readers. Prefectural and local school boards determine which publishers' textbooks will be adopted for a given school system in the case of public schools, and faculty make the determination in many private schools. All textbooks, however, must be certified by the Mombushō before they can be placed on the market. Because the Mombushō established guidelines regarding the style and content of the textbooks, and determines the constitution of the committees of scholars and educators who examine and license

\footnotetext{
${ }^{7}$ Ibid., p. 97.
} 
them, there is a high degree of uniformity among the series issued by the different publishing houses; what differences do exist are largely cosmetic in nature.

Mombushō control in fact extends to even the physical size and length of the textbooks. All are in paperback format, unlike the hardcover format of American textbooks, and all conform to the same dimensions. Textbooks for kokugo, social studies, mathematics, and science for grades 2-9 measure exactly $5 \% / 4$ inches wide by $81 / 4$ inches long. All elementary school textbooks are thin, light and pliant, easy to slip into a book bag and transport. (Children are generally not allowed to keep books in their lockers at school and must carry them home.) Small, light, and extremely portable textbooks would seem to be an incentive for their use at home by Japanese children, just as the heavier weight and more cumbersome dimensions of the larger, graphically more lavish American readers might militate against their use at home by American children (the 1989 Macmillan Press series "Connections," e.g., measures 8 by $91 / 2$ inches). The kokugo readers are also compact: reading, writing, vocabulary, and the introduction of Chinese characters are all integrated into a single thin volume. The Macmillan texts, by contrast, are supplemented by as many as eight large-size elective paperback workbooks per grade containing exercises on spelling, word meaning, reading, creative writing, story analysis, oral presentation, and drama activities, plus a workbook written in English and in Spanish for parents who wish to work with their children at home. Japanese textbooks are inexpensive and-unlike the far-costlier American textbooks, which are used for several years by succeeding classes of students-are not returned to the school after use. They are personal possessions of the children and, as such, can become extensions of the children themselves.

\section{The World as a Limited, Safe Place}

Elementary school readers in the United States today expose children to a view of a world made up of persons of diverse cultural and racial background with a wide array of problems and personalities, a world far removed from the safe, narrow, predictable vision of life presented to youngsters in the Dick and Jane readers 40 years ago. As early as the first grade, children read about youngsters their own age who have physical and social problems far more challenging than anything that ever confronted Dick and his sisters. There are characters who are blind or confined to wheelchairs; characters who are prey to the feelings of insecurity and inferiority created by sibling rivalry or parents who are socially disadvantaged; children who suffer or are self-conscious because they are too fat, or too tall and thin. There is an emphasis on caring for and assisting others, and children are depicted befriending and helping not only peers and equals, but members of the family and the community who are old, 
frail, sick, or handicapped. ${ }^{8}$ Indeed, one of the principles determining the selection of stories seems to be diversity. Being different is a positive value, and textbooks feature characters who exemplify a kind of individuality by virtue of some physical or psychological feature that makes them stand out.

In contrast to the current American emphasis on exposing children to the challenging complexities of life, Japanese elementary kokugo textbooks present the world as a safe, predictable place, a secure, protected environment where man and nature interact harmoniously. While the American reader presents difficulties children encounter and provides many examples of how children overcome their fears and their dilemmas, the Japanese reader seldom even acknowledges that children might have problems. Nor are children shown to harbor strong emotions. In comparison to the significant role it plays in American stories, desire, for example, as a motivating force is much more muted in Japanese stories. Japanese children are not often shown to have conflicting feelings or to struggle with their emotions, as children often do in American stories. Human figures in those stories are moreover usually depicted in rough, abstract fashion with little attention paid to individual differences. Children frequently all look alike, except for differences between girls and boys.

What is highlighted and celebrated instead is the natural world. In place of the large color photographs of children of different races found in the 1989 Macmillan readers, for example, the 1989 second-grade Mitsumura Tosho reader opens with colored photos of plants and insects, which give way to photos of landscapes in the upper grades. The most common perspective is the ground level perspective of the child. Attention is focused downward on the small forms of life that inhabit the grasses, seashore, and ponds of the child's world, as opposed to the images of flight (e.g., planes and trapeze artists) and ascent (mountain climbing) so often favored in American readers. The low ground-level line of observation places the child in a position of control over the bit of nature that he or she is taught to observe and write about. And within that narrow scope, the emphasis is on the same close observation of detail and procedure that characterizes Japanese elementary and junior high school science textbooks. Plants and insects that the child is likely to encounter close to home are presented in all their generic individuality, and children learn to distinguish and name three kinds of dragonflies, for instance, or name the stages in the life cycle of an akiakane (a kind of dragonfly). The focus on the natural world close to home nurtures a sense of familiarity and confidence vis-à-vis the surrounding environment.

\footnotetext{
${ }^{8}$ See the volumes Look Again, Friends Aloft, Adventuring, and Observing in the 1989 Macmillan “Connections" reading series, ed. Virginia A. Arnold et al. (New York: Macmillan, 1989).
} 
Whereas the inspirational messages that introduce the themes of the units of American readers are frequently related to themes of adventure and invention, those introducing Japanese readers emphasize the close interrelationships between people, plants, and animals. Eight-year-old children are likened to "young leaves" who, like the leaves of trees, prosper under the sky and the sun. ${ }^{9}$ The fluid ease with which natural forms interpenetrate each other is emphasized from the very first grade. A firstgrade reader, for example, begins with a story in which a class of children and their gym teacher mount a cloud that "looks like" a whale. ${ }^{10}$ The whale-cloud carries them out to sea but turns back when the school whistle signals the end of recess, as responsive to school rules as the children themselves. Nature as the ground of being is underlined in the titles of the textbooks (e.g., "Dandelion," "Dragonfly," "Blue Sky," "Young Leaves") and in the color photo frontispieces of dandelions, dragonflies (an ancient symbol of Japan) and flowers that are tied thematically to the stories.

The suggestion that children dwell in a protected space, at home in nature, is conveyed on the first page of the third-grade reader: "The sky is bright / above me here too / over that cow too / it lives over that mountain / over the pine tree too / everywhere the same clear blue." ${ }^{11}$ Third-grade youngsters in America open to page 1 of the 1989 Macmillan textbook, Adventuring, and find a message that is not only considerably more sophisticated but that implants a warning that all may not be well in the child's world: "Our language is full of surprises. In this unit, you will read about how communicating, or not communicating clearly, can lead to confusion." 12

Children in American textbooks are depicted as highly goal-oriented individuals who assume new responsibilities and gain mastery over themselves by facing new challenges. Children in Japanese stories tend not to have pivotal experiences that catapult them onto new stages of maturity. The world is a not a place of accident, motion, and change so much as a place in which the child is safely at home. The kokugo textbooks bring before the child familiar, positive features of the world. Some American stories (such as the numerous ones about blindness in the 1989 Macmillan "Connections" series), on the other hand, seem to be designed to bring the child face to face with what he or she may not know directly but may privately fear.

${ }^{9}$ Nobuo Ishimori et al., Kokugo san-ue Wakaba (National language grade three, vol. 1, Young leaves) (Tokyo: Mitsumura Tosho, 1989), p. 1.

${ }^{10}$ Nobuo Ishimori et al., Kokugo ichi-shita Tomodachi (National language grade one, vol. 1, Friends) (Tokyo: Mitsumura Tosho, 1990), p. 10.

${ }^{11}$ Nobuo Ishimori et al., Kokugo san-shita Aozora (National language grade three, vol. 2, Blue Sky) (Tokyo: Mitsumura Tosho, 1986), p. 1. Translations from Japanese are mine unless otherwise noted.

${ }^{12}$ Arnold et al., eds., Adventuring, p. 9 (see n. 8 above). 
This tendency to prolong the state of early childhood is a well-known facet of life in Japan. ${ }^{13}$ Like the Chinese, the Japanese have traditionally held the view that man's nature is inherently good, that human instincts can be trusted. Children are thought to come into the world unblemished, amenable to teaching. The notion that inborn selfishness and greed make it necessary that children subordinate their wills to the authority of their elders lest their characters be spoiled is alien to traditional Japanese views. Today as yesterday, young children are accorded special indulgences in the home and are rarely subjected to physical punishment at the elementary school level. ${ }^{14}$

As the scope and complexity of the world of the kokugo reader is limited, so too is the number of selections it contains. For each grade, $1-6$, there are two kokugo textbooks: volume 1 (ue) and volume 2 (shita), with seven to nine units in each. A unit consists of one or two reading selections followed by a skills developing section. Together the two volumes amount to fewer than 300 pages, less than half the number of pages in a typical hardcover reader of a basal reader series published in the United States, which may contain up to 36 units, with several reading selections and a skills developing activity in each. The teacher working with the kokugo textbook proceeds systematically, spending a week on each chapter. The broad selection of stories in readers such as the Macmillan "Connections" series requires the teacher to select some stories and skip over others.

The reading samples in the kokugo readers are not only fewer but represent a more modest array of text types than readers for comparable grade levels in the American series. Volume 1 of a 1988 fourth-grade Japanese reader published by Kyöiku Shuppan, for example, contains an essay (zuihitsu), two stories (monogatari), a student composition (sakubun), poetry (shi), two expository prose pieces (setsumeibun) on insects, a record of a scientific investigation (kirokubun), and a composition summarizing the results of a classroom experiment. Volume 2 contains two stories, two expository prose pieces, a children's story $(d \bar{o} w a)$, a poem, a composition, and the biography (denki) of a nineteenth-century village headman who engineered the construction of a famous stone bridge. (While the essay is labeled a "biography," its focus is not on the man's life but on the technical details of the water transport system that he devised.) A typical

${ }^{13}$ Joy Hendry, Becoming Japanese: The World of the Pre-school Child (Manchester: Manchester University Press, 1986), pp. 15-17. A more recent study of education at the preschool level is Lois Peak's Learning to Go to School in Japan: The Transition from Home to Preschool Life (Berkeley and Los Angeles: University of California Press, 1990).

${ }^{14}$ This all changes quite suddenly and radically, however, when the child enters junior high school. For accounts of physical punishment (taibatsu) meted out in junior high schools, see Ken Schoolland, Shogun's Ghost: The Dark Side of Japanese Education (New York: Bergin \& Garvey, 1990). 
fourth-grade American reader, the 1989 Macmillan Landscapes, contains stories, biography and autobiography, historical fiction, folktales, riddles, fantasies, book reports, tall tales, ballads, social studies articles, science articles, legends, historical stories, a fine arts article, a play, a photo essay, a science story, and a narrative poem: 49 different entries altogether, as opposed to 17 in the Kyöiku Shuppan reader. Japanese readers are organized according to principles of simplicity, uniformity, and a conservative estimation of children's needs and abilities. The American readers are inclined toward multiplicity, diversity, choice, and as becomes clear when one examines the rhetorical appeals of the texts, to an enlarged view of children's abilities and a desire to challenge them to expand their horizons and capabilities.

\section{Emphasis on Empathy and Feeling}

In addition to length and variety of text types, there is also a significant difference in the types of reaction that American and Japanese textbooks seek to draw from their readers. The American textbook places significantly greater emphasis on logical analysis, formal statements of principles, verbal definition of terms, and critical evaluative thinking. Children are introduced to activities such as distinguishing between true and false statements, reality and fantasy, fact and opinion; comparing and contrasting; and making judgments about whether actions are just or unjust, right or wrong. ${ }^{15}$ Analytical thinking is encouraged as the child is instructed to distinguish between main idea and supporting details, order a sequence of events, and analyze a story in terms of the elements of plot, setting and mood, character, and character's motives. Thinking involving causeand-effect relationships is emphasized. (There are even visual aids to cause-and-effect thinking, such as a diagram with a column of causes joined to a column of effects. $)^{16}$ The concept of first-person narration is defined, and children are instructed to "write in the first person." The notion of figurative expression is introduced and then refined with definitions of idiom, simile, and metaphor in the fourth-grade Macmillan reader (whereas the fourth-grade Kyōiku Shuppan textbook stops with the concept of an idiomatic expression). American children are invited to think in hypothetical terms, whereas the attention of Japanese children is fixed more on the concrete situation at hand.

${ }^{15}$ A fifth-grade instruction manual, e.g., includes for each lesson a section on guiding children in critical thinking. Ten-year-olds are asked to consider problems such as, "Did the emigrants have a right to settle on land that belonged to Mexico and Great Britain? Explain your answer," and "Do you think it was right of Mr. Edwards to have started a fight with the man from Huron? Explain your answer" (Virginia A. Arnold et al., eds., Landscapes: Teacher's Edition, "Connections" series [New York: Macmillan, 1989], pp. 189, 211).

${ }^{16}$ Virginia A. Arnold et al., eds., Sketches (New York: Macmillan, 1989), p. 481. 
Writing activities in the American readers are sequentially structured and involve a fair amount of formal reasoning. American children are taught to outline the development of an idea. They are taught the concepts of sentence and paragraph and are told that "the main idea is often stated in a sentence which is many times the first or the last in a paragraph." 17

The emphasis in kokugo texts on empathy and subjective feeling is readily apparent in the titles to the introductory units of the texts at all grade levels. Children learn to "think about feelings" (kimochi o kangaete), to be aware of the ways in which "heart speaks to heart" (kokoro no kayoiai), and to "attune their hearts" (kokoro o kayowaseru). Children are taught to examine their emotional reactions to stories, and to do this on the basis of close self-observation. They write descriptions of their impressions (a genre known as kansōbun) and the ways to do this are carefully enumerated, as in this set of instructions following one frequently anthologized story about a man and a fox: ${ }^{18}$

1) First introduce a summary of the story and then write about what you felt and thought when you read it.

2) Introduce the events of the main scenes and then write about what you felt and thought at each scene.

3) Focus on the scene that left an especially strong impression and write about what you felt and thought.

4) Without introducing either a rough summary or the scene, gather together your impressions and opinions regarding the whole of the story. ${ }^{19}$

While American textbooks tend to encourage the child to step away from the story and to analyze the situation and the actions of the characters and to evaluate the effectiveness of their actions, kokugo textbooks often invite the child to imagine the feelings of another and to merge his or her identity with that of the character, even if that character should happen to be an animal. Children reading the story "Gon the Fox" are instructed to "become Gon the fox and address Heiju [the farmer who accidentally shoots Gon], and then become Heiju and talk to Gon."20 They are not so much encouraged to distinguish between fiction and fact as to enter imaginatively into the fictive world. "Write a letter in which you write as if you were talking to Heijū," read the instructions following the story.

${ }^{17}$ Ibid., p. 170.

${ }^{18}$ Kokugo textbooks contain not only detailed instructions for writing but also many models of student compositions. This is in keeping with the traditional Japanese way of teaching an art or a skill through close modeling and repeated practice. See Victor Nobuo Kobayashi, "Tradition, Modernization, Education: The Case of Japan," Journal of Ethnic Studies 12, no. 3 (Fall 1984): 106-14. See also Catherine C. Lewis, "Creativity in Japanese Education," in Japanese Educational Productivity, ed. Robert Leestma and Herbert J. Walberg, Michigan Papers in Japanese Studies no. 22 (Ann Arbor: University of Michigan, Center for Japanese Studies, 1992), pp. 224-45.

${ }^{19}$ Junji Kinoshita et al., Shōgakkō kokugo yon-shita (Elementary school national language grade four, vol. 2) (Tokyo: Kyōikyu Shuppan, 1988), pp. 24-25.

${ }^{20}$ Ibid., p. 23. 
Children are furthermore taught to share their impressions and feelings. They are instructed to read a story aloud in a way that brings the scene under description vividly alive to their listeners and to discuss their impressions of the story together with their friends. The role of the kokugo textbook in promoting group harmony and molding a common consciousness is reflected especially in this emphasis on oral reading and discussion. The group effort is underlined by instructions that are cast in the presumptive "let's . . ." and "shall we . . ?" sentence patterns that involve both speaker and listener in a mutually cooperative mental effort. Children also receive instructions on how to modulate their voices to fit different types of speech acts (inquiring, inviting, encouraging, urging, etc.).

Language in these textbooks is treated as a means of expressing affective states of mind. Children are taught to be sensitive to the emotional effects of the words they use, such as the effect of writing a message using Japanese words, as opposed to Sino-Japanese words ("Kotoba no Kanji" [The feeling of words], fifth-grade reader, vol. 2, Mitsumura Tosho, 1991). There is almost no grammatical analysis. When an analytical approach is summoned, it is directed to the exploration of the behavioral phenomenon of plants, insects, or fish, or it is focused on a practical physical experiment rather than on a social situation. Human actions are not analyzed and critiqued from a perspective of right and wrong, just and unjust. Children are taught instead to observe closely, to be sensitive to the nuances of feeling in others, to imagine and to empathize with those feelings, and to be understanding and cooperative. The basis of the reading activity is not so much the commonality of logical thought as it is the commonality of feeling as children are exhorted, "Let's manage to read so that we convey to the listener the appearance of the scene and the feelings of the character."21 The kokugo textbooks teach children to attune their sensitivity not only to the feelings of other people, but also to nature.

\section{A Nature-centered View of the World}

In the midst of the ongoing debate in the United States about whose experiences and what kinds of experiences should be represented in textbook literature, coming face to face with the world of kokugo stories in which human protagonists drop out of the picture altogether can be startling and disconcerting. Instead of stories about courageous, innovative, individualistic people who surpass physical and psychological limitations, one encounters stories about plants, insects, frogs, fish, foxes, and monkeys. Oftentimes the human observer, while present at the beginning of the story, will have faded away by the story's end. The specific consciousness

${ }^{21}$ Junji Kinoshita et al., Shōgakkō kokugo yon-ue (Elementary school national language grade 4, vol. 1) (Tokyo: Kyōiku Shuppan, 1988), p. 4. 
of the individual self, so central and consistently present from beginning to end in American stories, becomes a neutral, general consciousness that presides over but does not intrude into the world of the kokugo story.

The relative insignificance of the human figure in the world of the kokugo reader is not surprising when taken within the context of traditional Shinto and Buddhist views of the unity of all forms of life. Here one might recall that Japan is a nation where priests once debated whether plants possessed a Buddha nature and where poet-priests like Saigyō (twelfth century) and Bashō (1644-94) polished their craft composing poems about plants and insects. A glance through a list of modern Japanese stories by leading authors turns up titles such as "Rain Frogs," "The Wagtails' Nest," "The Grasshopper and the Bell Cricket," "The Red Frog," "The Centipede," "The Wasps," and "The Red Cocoon."22 The very sign for "word" is written with the characters, "speech-leaf." Stories about nature in the elementary grade kokugo readers mark a route that will eventually lead young readers in the junior and senior high school years to the Manyosh $\bar{u}$ (A.D. 759), popularly known as "The Collection of Ten Thousand Leaves," an anthology of poetry that celebrates the natural beauty of the lush botanical environment in which the early Japanese found themselves, and to classical works such as $H \overline{o j} j \bar{k} i$ (A.D. 1212, A record of my hut) and Oku no Hosomichi (A.D. 1689, Narrow road to the back country) in which aesthetic and spiritual encounters with nature are central.

Traditional religious and philosophical teachings of Japan encouraged a passive attitude toward nature; people gained spiritual depth through the contemplation of natural phenomena. Characters in kokugo textbooks act within this tradition of contemplation and meditation and by example teach young readers to be sensitive to small changes in the environment. A sick boy spends an entire day watching the play of light on a chair left out on a beach from the window of his hospital room in "The Chair at the Beach" ("Hamabe no Isu," third-grade reader, vol. 1, Mitsumura Tosho, 1987). A boy hopes for good weather on his birthday in "The Birthday" ("Tanjōbi," fifth-grade reader, vol. 2, Mitsumura Tosho, 1988). When the awaited birthday finally comes around, anticipation is heightened by the jingling of a tiny bell that he carries in his pocket (a gift from his sister), and the highlight of the day is a beautiful falling leaf, an event which is experienced privately, poetically, and in extraordinary quietude.

The 1988 fourth-grade (vol. 1) Kyoiku Shuppan reader begins with a zuihitsu essay entitled "The Little Mud Flat" ("Chiisana Higata"), in which the first-person protagonist records his emotional reactions to the

${ }^{22}$ From Stories by Shiga Naoya, The Paper Door and Other Stories, trans. Lane Dunlop (San Francisco: North Point Press, 1987); and A Late Chrysanthemum: Twenty One Stories from the Japanese, trans. by Lane Dunlop (Tokyo: Tuttle, 1988). 
migrating birds that come to a mud flat near his home. The speaker describes a small mud flat near his house which exists only during low tides; the rest of the time it is an indistinguishable part of the ocean. It is home to crabs, shells, shrimp, and small fish. The "I" informs the reader that, when he has time, he shoulders a telescope and sets out for the shore of the mud flat to look at the birds that gather there. Viewing and the personal reaction to what is seen constitute the content of the essay. "The sight of birds hunting for food, quarrelling, and flying about fills me with happiness." In traditional Japanese essay style, the narrator situates his point of view within a season. "In March the water of the mud flat looks cold and the grass and the earth on the shore still wear wintry colors. The winter birds are lined up and are basking in the sun, and the seagulls are flying slowly." The tone is subdued; the only suggestion of drama is the appearance of brightly colored sandpipers that fly in from the south to give the mud flat an appearance of spring. "The sandpipers are messengers that bring spring to Tokyo Bay." The narrator describes the bird's size ("a bit bigger than a pigeon but with its long bill and legs it looks quite large") and describes the peculiar shape of its bill, which lends it the name, "bent-bill sandpiper." The narrator talks about the bird's diet, its migratory habits, and the way its chest and stomach turn bright brick red. Toward the end, the focus broadens to include the sight of other birds.

"The Little Mud Flat" is very much in keeping with the Japanese tradition of essay writing. A zuihitsu is not a logical exposition of a position, but a personal miscellany or lyrical evocation, often a recollection, of nature scenes. This zuihitsu is typical in the quiet, understated presence of the narrator, whose activity is limited to observing, and whose absorbed observation carries him into the very being of the bird itself: "I too tried imitating it by standing on one leg, but I got tired right away. . . I admired them for being able to remain standing on one leg for a long time."23 The self identifies with and merges with nature. It never become a fully constituted "personality," the way it does in a fourth-grade Macmillan reader nature story, "The Living Desert," where the narrator is grounded in a social context and interacts continuously and vigorously with other characters who have names and sharp-edged personalities. Although ostensibly about nature, this story is filled with a medley of voices that seem to drown out the sounds of nature:

I began to have a feeling that something was missing. I finally realized what it was. "There's nothing here," I remember blurting out to Jan.

Jan didn't get my point at all. For her, there was plenty there-all kinds of low-growing plants and grasses, cacti, and bushes. She could have spent a year and still not investigated all the plants in that desert.

${ }^{23}$ Kinoshita et al., Shōgakkō kokugo yon-ue, p. 8. 
"I mean there are no living things," I said.

She was annoyed. "What do you think all those plants are?"24

Other stories about animals and nature in this American reader are even more striking for the active intervention of human beings in the lives of animals. In "Elisabeth and the Marsh Mystery," the unexpected appearance of a stray sandhill crane prompts a family to enter a swamp in the middle of the night to stalk it, catch it, and transport it by truck to an airport so that it can be shipped to a wildlife refuge in Indiana to join a large flock of sandhill cranes due to arrive there. In the prizewinning story, "The Trumpeter Swans," a pair of trumpeter swans are saved from a fox by a boy who suddenly appears on the scene to intervene in their lives. Like many American children's stories, this story is marked by a strongly anthropocentric view of nature; the male and female swans are referred to as husband and wife and are invested with human perceptions and reactions: "The cob's wife pretended not to notice that her husband was showing off, but she saw it, all right, and she was proud of his strength and his courage. As husbands go, he was a good one." ${ }^{25}$ In Japanese stories about animals, people are not only less energetic about helping animals; sometimes, as in "Gon and the Fox," people are definitely inferior to animals, which come across as more understanding, more generous, and wiser; in short, more humane, than humans.

The active, as opposed to contemplative, orientation toward nature in American readers can also be seen in the nature of the questions posed at the ends of the stories. Children reading the story about the sandhill crane are asked, "What extraordinary thing did the sandhill crane do? Why wasn't the crane frightened by all the people who had come to find it? Do you think the sandhill crane could have found its way to Indiana without help? Explain your answer." 26 These questions reveal the tendency to analyze and dramatize events in nature, which contrasts with the Japanese tendency to quietly lose the self in the contemplation of nature. Japanese children are told at the end of "The Little Mudflat" to "read while paying attention to the parts where the mood of the season is described," and "to read aloud in such a way that the appearance of the sandpipers is clearly conveyed to the listener." 27

In the kokugo reader, small forms of life emerge with crystalline clarity in a setting emptied of human need and intention. One reads about camouflages used by fish; the growth of a gourd plan, the life cycle of a frog; how a dandelion propagates seeds; stages in the life cycle of a dragonfly; the life stages of a salmon, and the behavior mechanism of

\footnotetext{
${ }^{24}$ Arnold et al., eds., Sketches, p. 422.

${ }^{25}$ Ibid., p. 514.

${ }^{26}$ Ibid., p. 509.

${ }^{27}$ Kinoshita et al., Shōgakkō kokugo yon-ue, p. 9.
} 
ants that enables them to find their way back home. One sixth-grade reader (vol. 2, Mitsumura Tosho, 1990) features a story narrated by baby crabs at the bottom of a stream. The drawings accompanying the story, which reproduce with geometric shapes the impression of sunlight refracted on the surface of the stream viewed from below the water's surface, are striking for the abstract unanthropocentric perspective they give of the crabs' world.

Nature provides not only setting and subject but lessons for living in the kokugo textbook. Second graders begin the new school year, in April, by reading (in the 1989 and 1992 Mitsumura Tosho readers) "Fukinoto" ("Swamp Cabbage"), a little parable about symbiotic cooperation and harmony in nature. Tree tops obligingly sway their heads to allow sun rays to melt the snow and enable a young struggling swamp cabbage to expose its head to the sunlight. Sacrifice for another is taught by the hirugao (literally "daytime face") flower, in the third-grade story "Hirugao" (Kyoiku Shuppan, 1984). The protagonist is a convolvulus or hirugao that lives on the beach. A recent storm has swept sea water containing a small fish into the rock crevice by which the flower dwells. "Hirugao" has become good friends with the fish, and realizing that the fish will die if the trapped water evaporates, prepares to sacrifice its life by asking the human narrator to wrench it from its soil to prevent the sun from coming out and drying up the pool of water. (According to popular folk belief the sun will come out when the hirugao blossoms.) A slightly less extreme degree of solicitude is displayed by a lizard in the story "Spring Bicycles" ("Haru no Jitensha") in a 1984 Kyöiku Shuppan third-grade reader. The lizard enjoys sunning itself on the steps of a shrine on an early spring afternoon, but worries about the fate of its cousins, the frogs, when it hears the bells on the bicycles of the village children. In an interesting twist, inhabitants of the animal world that traditionally serve to signal seasonal change for humans, are here the readers of signs, and human beings, the signs to be read. These bicycle bells are for lizards and frogs, harbingers of spring, and with spring comes the danger of being squashed to death by bicycle wheels.

Currents of sympathy flow not only between people, plants, and animals in these textbooks; even inanimate things can become objects of empathetic concern. In "Sedge Hat Jizō's" ("Kasako Jizō," second-grade reader, vol. 2, Kyōiku Shuppan and Mitsumura Tosho, 1991), statues of Jizō, the guardian deity of children whose cap-and-bib clad image can be seen throughout Japan, come to life and bring food to an old man who covered their heads with sedge hats to protect them from a snowstorm. Stories like this teach the moral value of returning a favor (on-gaeshi) and present the world as a safe, predictable place where even inanimate beings may return kindness with kindness. Not even death marks a rupture in the 
continuity of relationships that constitute the child's safe, happy world in the story "Suho's White Horse" ("Suho no Shiroi Uma," second-grade reader, vol. 2, Mitsumura Tosho, 1991), a Mongolian folktale about the origin of the horsehead fiddle retold by Yūzō Ōtsuka. Suho's white horse makes its way back to him after it has been shot by arrows, and with its dying breath instructs Suho to fashion a lute from its bones, sinews, skin and hair. By playing the lute that is magically invested with the spirit of the white horse, Suho will be with his horse forever after.

It is significant that the nature featured in kokugo textbooks is mostly the nature of the Japanese islands. There have been to date relatively few stories about nature outside of Japan. An appreciation of the splendours of the globe and the inculcation of a sense of awe toward the physical universe do not appear to be the goals of the kokugo reader.

\section{The Image of the Happy Yamato Family}

The attention devoted to nature in the kokugo textbooks, together with the pronounced focus upon the growth of plants and insects in the science textbooks in grades 1-6, provides urban children with a link to a natural environment that is rapidly being eroded in today's highly urbanized Japan and contributes to the creation of the image of a common agrarian past (until the end of the nineteenth century, 80 percent of the population was rural). Nature, and the experience of a particular kind of naturethat is, the plants, insects, meadows, fields, streams, and mountains of the Japanese islands-become touchstones for life as a Japanese person. Children dissect the same plants that their parents and grandparents knew as children, fashion boats from the same leaves, plant the same seeds, and catch the same insects. And in repeating the childhood experiences of their ancestors, they are led to "discover" an enduring common identity, rooted in nature, amid the alienating environment of the larger cities. Growing urbanization and modernization in Japan has been accompanied by growth in the idealization of the agrarian past of the Japanese people, of which the commercialization of the image of the furusato, or old home village, now used to sell food products and promote tourism within Japan, is but one obvious example. The kokugo textbook contributes to the construction of this mythic communal past through its images of nature and through traditional folktales and nostalgic stories about childhood visits to ancestral villages in the countryside that transport the young reader back to the rural past with the now grown-up urban narrator whose perspective she or he shares.

The Japanese children who are members of this idealized amorphous family with roots in the countryside tend to be vaguely suggested, tentatively adumbrated sketches of girls and boys. The faces and bodies are faintly illustrated with light ink and paint washes and are frequently depicted in 
a manner that abstracts and flattens their phyical features to cartoon-like dimensions. Unlike characters in American readers, unique individuals with unique problems whose distinctive features are illustrated with strong line and color in large-size pictures, Japanese kokugo children seldom have surnames and often not even first names.

When a child's uniquely individual circumstances and proclivities are stressed, the child is likely to be a character in need of remolding to fit the norm; for example, a girl named Sawada Tamiko in "Sawada's Mole" ("Sawada no Hokuro," fourth-grade reader, vol. 1, Kyōiku Shuppan, 1988) who bears a distinctive large mole in the middle of her forehead and whose figure is, uncharacteristically, well-defined in pen-and-ink drawings accompanying the text. Sawako's physical blemish creates a character flaw. She is inordinately self-conscious (the ideal Japanese child is a happy, energetic, and unself-conscious), and, to hide the mole, she grows long bangs that hang curtain-like down to her nose. Whereas many American stories follow a script in which a child's attempts to solve a dilemma constitute the events of the narrative, typically, in this Japanese story, the solution is not worked out by Sawada but is imposed from without by a figure in position of authority. And the problem is not simply the boys in the class who tease Sawada by calling her "Daibutsu no osekkai" ("Great Buddha busybody"), an allusion to her mole, which resembles the urna on the forehead of the Buddha, and to her habit of officiously taking classmates to task for breaking rules. On the contrary; Sawada herself is seen to be at fault because her self-conscious behavior disrupts social harmony. Her long bangs, which she holds to her forehead even when she works out on the parallel bars and does vaultjumping exercises in gym, prevent her from participating according to form and call undue attention to herself.

The teacher in this Japanese story does not reprimand the boys and teach them to tolerate other people's differences, as she might were she a character in an American story. When Kimura Sensei finally intervenes, it is not to spare Sawada's feelings, but to make Sawada an object lesson in mutual support and group unity. "If a friend were uncomfortable about something and it made her very sad, what would you do?" she asks the class. "Wouldn't you want to help her?" In a dramatic gesture, Kimura Sensei makes all the students close their eyes while she brings Sawada to the front of the class, combs her hair, ties back her bangs with a barrett and a blue ribbon, and then turns her around to face all her classmates. The children are instructed to open their eyes to view the new Sawada. The teacher invites a response from all those who promise to never tease Sawada again and the children cry out, "Yes" as they raise their hands.

At the end of the story there are instructions that urge young readers to identity themselves with Sawada: 
Let us try to read the following sections as we imagine ourselves in Sawada's stead

1. when she was told by Kimura Sensei to cut her hair;

2. when she had her bangs parted by the teacher in front of everyone;

3. when Mitsuo called her "Great Buddha Busybody." 28

While Sawada is singled out by others because of her aberrant appearance and behavior, considerations such as her right to privacy or the integrity of her inner self that might be injured when she is put on display by the teacher do not enter the picture.

If one of the goals of textbooks is to develop constructive social attitudes in children, the kokugo textbooks have only barely begun to address the problem of bullying (ijime) that has plagued Japanese junior high schools for some time. Much of this bullying is directed against children who are perceived as being different from the majority. Children who are physically weak, who do poorly in school, who dress differently, or have different accents may be subjected to bullying, which may range from name calling to physical attacks that end in death. ${ }^{29}$ While some folkloristic stories in the textbooks do contain dialogue written in regional dialect, one kind of diversity, the textbooks have been slow to treat the idea of diversity itself. Insofar as they seldom acknowledge that differences do exist, the textbooks cannot be said to contribute to the tolerance of individual differences. They are in fact striking for their seeming insistence on a unified homogenous people residing on the four main islands of Japan. While regional customs and festivals are noted, they are those of regions within the four main islands; peoples living farther south, on Okinawa, or on any small island, are not mentioned. And while stories about American Indians are almost obligatory in American textbooks today, the aboriginal Ainu, for example, do not appear in kokugo textbooks. Nor is the existence of minority Korean, Chinese, or burakumin (members of communities of social outcastes), or children of mixed-race marriages, acknowledged. Unlike American textbooks, where young people are often shown helping and comforting older people, Japanese textbooks seldom acknowledge the existence of the elderly, other than as characters in fairytale settings.

In spite of the fact that Japanese children are made keenly aware of the ways in which success in school leads directly to coveted positions in the adult world, children in kokugo textbooks are not depicted competing in school, nor are the social differences that result from school performance alluded to.

${ }^{28}$ Ibid., p. 23.

${ }^{29}$ For an extended report on cases of bullying (ijime) as well as corporal punishment in Japanese schools see Schoolland ( $\mathrm{n}$. 14 above). A rather unusual dramatization of the dynamics of bullying is found in a story in a 1991 sixth-grade Gakkō Tosho reader entitled "Roshia Pan" (Russian bread), in which a village schoolboy is heckled by junior high school classmates for "harboring a spy" because he is on friendly terms with a Russian family living next door. 
Unlike social studies textbooks, the focus of the kokugo texts is not on society, and, for a country as densely populated as Japan, the stories tend to be very thinly populated. Unlike American stories where children are often shown making new friends, kokugo textbooks contain few stories in which a child confronts a stranger; when such stories do occur, they are often set in the past, where, for example, a city child encounters a group of village children. Before 1992, stories in which foreigners appeared were rare.$^{30}$ One interesting exception is the story of a man's posting to India and his children's successful adjustment to life there, which appeared in the second volume of the 1990 sixth-grade Mitsumura Tosho reader. The frontispiece of the text departs from the usual scenes of Japanese nature and introduces photos of Jainpura and Indian children. But the story is entitled "Connecting Hearts" ("Kokoro o Tsunagu") and significantly dwells on the importance of feelings. The author writes that his elder son was able to communicate successfully with Indian friends not only because he could speak Hindi and English, but, more important, because he had cultivated the "Japanese" skill of communicating "heart to heart." $\mathrm{He}$ goes on to say that forgetting about the heart and attempting to persuade someone with words alone just will not work; indeed, the important thing is the heart (p. 89).

\section{Memories of the Pacific War}

Of all the subjects contained in the kokugo readers, the Pacific War is probably the single most rhetorically powerful means of creating a national consciousness and sense of belonging to a people with a common history. The war has occurred with significant frequency as a theme especially in the third and fourth grades. (In the 1992 Mitsumura Tosho reader, however, the war story appears in the sixth-grade reader.) In the 1988 and 1989 Mitsumura Tosho readers and the 1988 Kyoiku Shuppan reader, the central significance of the story about the war is underlined by the frontispiece color photograph of cosmos flowers, the kind featured in the story, "One Flower," which appears in all three readers.

As if to emphasize the helplessness of the Japanese citizenry that suffered the bombardments, the hunger, and the defeat, most of these stories are about young girls. Through these small girls Japanese children

\footnotetext{
${ }^{30}$ The story "Roshia Pan," alluded to above, is an exception. The incidents of the story take place in the early thirties, around the time of the Manchurian Incident, soon after which the Russian family leaves the boy's village for an unknown destination and is never heard from again. The narrator and his family know almost nothing about the Russians or why they have come to Japan. And while the remarks of the Japanese school children about the family are rendered in a vivid, realistic manner, the narrator's account of playing with the Russian boy gives no indication of the boy's personality, nor do his comments about the Russian family ever make the foreign individuals "come alive." Despite physical proximity and frequent contact, the family remains isolated and cut off in the narrator's consciousness.
} 
are led to see the war as an event that overwhelmed the Japanese nation, much as any other natural catastrophe, an event in which they were helpless victims swept up by forces that they could neither understand nor control. By shifting the focus at the end of these stories from war time to the present or near present, the authors invite contemporary school children to identify with the children in the story. The war becomes a national event that all Japanese shared; as part of each Japanese person's past, it becomes integral to the Japanese identity. The wartime stories' focus is on the deprivations suffered by the citizens on the main islands of Japan (excluding Okinawa, where civilians perished or, as some would say, were sacrificed by the Japanese military, in great numbers in the last days of the war). Men are generally absent from these stories. They are away at the front or have already died in battle. When present, they are depicted as gentle, weakly men who are good to their children, often wear eyeglasses, and are among the last to be conscripted.

The suffering caused by lack of food is a common theme. In "One Flower" ("Hitotsu no Hana") little Yumiko has learned that the words "please give me just one" will often yield a single potato or a piece of squash to quell her gnawing hunger. The planes come daily and the city is reduced to rubble. The day comes when even her sickly father is called up. Yumiko is carried on her mother's back when the family goes to the station to see him off. Not wanting to send her husband off to war with the image of his child's crying face, Yumiko's mother gives her the last riceball in her knapsack. By the time they arrive at the station where the recruits have congregated Yumiko is clamoring again for "just one." She begins to cry, and her father disappears to find something to appease her hunger. He returns with his farewell gift, a single cosmos flower which he has found growing on a garbage heap. At the sight of the bright flower Yumiko forgets her hunger and wriggles with delight. The father boards the train wordlessly, with his gaze fixed on the flower in his daughter's hand, and smiles as the train pulls away. Ten years later, we are told, Yumiko no longer remembers her father's face, or that she even had a father, but the small hut in which she and her mother live is surrounded by cosmos flowers.

The flower exchanged at the moment of farewell in this story resonates with significance. The image of the single flower harks back to the story of the origin of Zen Buddhism, the moment when the Buddha silently held aloft a flower, a gesture to which Kāshyapa, one of his close disciples, reacted with a smile of recognition, and thus marked the first transmission of the dharma. The cosmos flower growing in the garbage also recalls the lotus, symbol of Buddhism, rooted in the mud. The association between flowers and the passing on of a tradition lives on powerfully today as a central ritual of the contemporary wedding ceremony, where the bride 
and groom present their parents with flowers to acknowledge the ties that bind children to parents.

The episode of the giving of the flower in "One Flower" is also linked to past aesthetic traditions through the sensibility of aware, the sensitivity to fragile perishable beauty that recalls the ephemerality of life. Of all the images in classical literature associated with aware-moonlight, snow, dew on autumn grasses, the cries of insects, the flight of birds - none was used as frequently as flowers. The story also recalls literary conventions of the past in its elliptical linkage of events and use of images to communicate situation and state of mind. That Yumiko's mother feeds her daughter in the postwar reconstruction era by doing piece work at home is conveyed by reference to the sound of a sewing machine. That this little family will survive is suggested through the image of the many cosmos flowers surrounding the hut, flowers through which Yumiko, now playing at being the "little mother," passes on her way to market. The absence of explicit narrative explanation and the communication on the level of symbol and suggestion are in keeping with the traditional emphasis on feeling and intuition and is yet another way in which the textbooks help to mold a sensibility that will be further reinforced through the classical literature encountered in the junior and senior high school kokugo textbooks.

Many of the stories about the war are thus centered on a humble object that provides a link between the prosperous present and the war years. Keepsakes fashioned by the hands of those who suffered and sacrificed during the war are prized far more highly than any goods that can be purchased with money today. Dolls carved from pencil stubs by a rough country boy and given to a city girl who was evacuated to his mountain town are such objects in "The Pencil Dolls" ("Empitsubina," second-grade reader, vol. 1, Nihon Shoseki, 1989). Having given her two pencil dolls, representing the emperor and the empress dolls of the traditional girls' day festival, the boy, who tries to make the newcomer feel welcome, promises to bring the rest of the court dolls to school the next day, but that night, the part of the town where he lives is bombed, and he perishes along with the rest of his family. The girl, grown up, treasures the priceless pencil dolls and tells their story to the current generation of elementary school children.

The travails of their owners invest such objects with a spiritual quality that becomes a legacy left by the generation of children who lived during the war. These stories convey traditional moral virtues such as sacrifice, effort (gambare), and endurance (gaman). In "Mother's Paper Dolls," ("Okaasan no Kamibina," third-grade reader, vol. 1, Kyōiku Shuppan, 1984) a woman tells her young nieces the story of the paper dolls that her mother made for the dolls' festival during the war. Growing up during wartime, the narrator is always hungry, and her mother sells the court 
dolls that have been in the family for generations to buy white rice for her to eat. When the girl sees her mother folding origami paper dolls to display on the festival day, and learns that the dolls that have been evacuated along with the family have been sold, she calls the paper dolls hateful and throws a tantrum. The mother weeps silently and continues to fold the paper into dolls. The shock of seeing her mother's body shaking with grief jolts the girl into an awareness of her selfishness. Overcome with a feeling of shame, she resolves to do her share and sets to folding paper dolls alongside her mother. The father never returns from the Pacific Islands, and the paper dolls become her most treasured possessions. Now she shows the dolls to her young nieces and tells them the story of "mother's paper dolls" to teach them the way her mother struggled through difficult times during the war.

Continuity of life during and after the war is suggested by recurring visual and auditory images of the river in "The River and Norio" ("Kawa to Norio," sixth-grade reader, vol. 1, Kyōiku Shuppan, 1983) and the sound of the mortar used to grind soybeans in "The Song of the Mortar" ("Ishiusu no Uta," sixth-grade reader, vol. 1, Mitsumura Tosho, 1989 and 1992). Both stories are set in the countryside around Hiroshima in the summer of 1945. The gurgling sound of the stream and the grinding of the pestle against the mortar are images of homey comfort that contrast with the unarticulated horror of the bombing that runs as a subtext throughout the stories. The bombing is never described directly, but alluded to through its effects: the mothers of the child protagonists never come back from visits to the doomed city and the children are left behind with grandparents. Norio's father who went off to war as a soldier does come back, eventually. Father, we are told with breathtaking understatement in the next sentence, "was a little box." The idea that the father's ashes were contained in the box, which would normally be expressed with the words hako no naka ni arimashita ("were in the box") or hako no naka ni irete arimashita ("had been placed in the box"), is condensed to hako deshita, "was a box," a formulation that summarizes Norio's loss with startling abruptness. At the end of the story, the orphaned Norio cuts grass for his pet goat alongside a river that seems to repeat the refrain, "mother come back, mother come back."

If the story about Norio emphasizes a boy's dependency on a lost father and mother, the story about a girl emphasizes the need to be strong and to carry on. The different messages for boys and girls is consonant with the general tendency in Japanese society to indulge young boys and to make girls more responsible for controlling their impulses. Chieko is selfish and bored at the beginning of "The Song of the Mortar" as she and her grandmother grind the soybean flour for the observance of the annual August festival of the dead, but she becomes filled with resolve 
to live for others after her parents perish in Hiroshima on August 6 . "Study, study - stand up no matter how hard things get," sings the mortar at the end of the story. The legacy of the war is redoubled effort for this young female child.

The war is never depicted in its early days of euphoric victory, but in the last days, when the very weakest and unfit of the men were conscripted and women and children ran for their lives into bomb shelters. The drawings that accompany these stories are rendered in ink and light washes of brown and grey, so that the wartime events seem to transpire in the dim shadows of distant memory. The war years constitute a yawning void into which fathers stepped, never to return, and entire families disappeared. At times the message of victimization in the war comes across in a sudden shocking way.

In "Chiichan Casts a Shadow" ("Chiichan no Kageokuri"), anthologized in third-grade readers published by Mitsumura Tosho in 1987 and 1991, the world of innocent children's play and the world of death come together with astonishing suddenness. On the way home from visiting the ancestral graves, a father teaches his daughter Chiichan, her older brother, and his wife a game that he played when he was a boy. The family of four hold hands, stare hard at their shadows, and at the count of ten look up at the sky where their shadows appear to leap up. The father jokingly calls the shadows their "commemorative photograph." The next day "even this man with the weakly physique" goes off to war. Chiichan and her brother continue to play games with their shadows until planes loaded with incendiary bombs transform the once wide pleasant sky into "a fearful place." One night Chiichan is awakened by air raid sirens. A strong wind blows and fires dart up all around. Mother, son and daughter flee their home and in the melee, Chiichan becomes separated from her mother and her brother. She spends the night with a group of refugees under a bridge and the next morning makes her way back home, where she waits all day for her mother and her brother to return. That night she eats a little dried rice from a cloth bag and sleeps inside the crumbling dugout. A cloudy day dawns, and another dark night comes. Chiichan eats a bit more of the dried rice and falls asleep inside the dugout. On the third morning bright sunlight strikes her face. She feels hot chills and her throat is terribly dry. The sun is in the sky when, "The sky is just right for sending your shadow," her father's voice comes down from the blue sky. "Yes, let's all do it together," her mother's voice also comes down from the blue sky. Chiichan stands up on shaky legs and staring hard at her shadow, begins to count. "One, two, three." Soon her father's low voice is counting along with her. She hears her mother's high voice joining in. And then her brother's laughing voice chimes in, "T-en." 
When Chiichan looks up at the sky, there are four white shadows clearly outlined in the blue sky. She calls out, "Father, Mother, brother." At that moment she realizes that her body has become completely transparent and that she is being sucked up into the sky. The color of the sky stretches out before her. Chiichan is standing in the middle of a skycolored field of flowers at the top of the sky. "I've floated up here because hunger made me so light," she says. At that moment she sees her father and her mother and her older brother walking toward her. They are laughing. "So that's why you didn't come for me. You were all up here." Chiichan begins to laugh brightly and runs through the field of flowers.

The author ends the story with the statement: "And thus the life of a little girl disappeared into the sky one morning in early summer." And adds in a postscript: "Ten years later, many more houses than before filled the town. The spot where Chiichan sent her shadow up has become a small park. Today beneath the blue sky a boy and a girl about the age of Chiichan and her brother are laughing as they play."

Some images of the war take a more violent, graphic form. "The Angry Jizō" ("Okoru Jizō," third-grade reader, vol. 1, Nihon Shoseki, 1989), is set in Hiroshima itself on the day the bomb falls. The main protagonist is a statue of Jizō, the guardian deity of children, who stands by the wayside in a neighborhood in Hiroshima and is affectionately addressed as "Smiling Jizō." It is the morning of August 6. In most of the stories about the war, the bombings are treated as more or less apolitical natural catastrophes, and information about with whom or why the Japanese are at war is not given. In this story, however, 8-year-old readers are furnished with the explicit information, "an American B29 bomber was sighted in the air" and there was a blinding flash of light, "as bright as if the sun had fallen." "It was an atom bomb." Its effects are described vividly: windows, pillars, and people are blown into the sky, catch fire, and rain down upon the earth. The Jizo statue is swept into the air, splits in two, and his trunk is buried in "hot burning" sand. Only his laughing face remains.

The story departs from the usual treatment of the war by describing the wounds and burns suffered by the victims. People wrapped in burning clothes run by. Mothers with scorched hair carrying dead babies, children with faces swollen with burns stumble past the head of the Jizō. They cry out: "Run!_" "It hurts_-" "Help!_-" Looking up from the sand, the head of the Jizō sees the columns of fire rising into the sky. The next day the head is among the many dead bodies that lie scattered about the burned out landscape. A little girl in a blue dress who used to pat the Jizō now reappears in the distance looking ever so much like a rag blown by the wind. Only a bit of faded blue is discernable on the charred cloth 
that hangs from her body. She totters toward the Jizō and falls to the ground. A large red burn "shaped like a peony" covers her back (and is rendered in one of the almost abstract drawings that illustrate the story). She calls for her mother ("kaasan") and begs for water. The head of the Jizo strains, and his laughing expression disappears, replaced by the ferocious expression of a heavenly guardian king. ${ }^{31}$ As the girl continues to call for water in a voice that grows fainter and fainter, tears from the Jizō's glaring stone eyes flow faster and faster, roll across the sand, and fall into her mouth. Aided by the Jizō's tears, she dies peacefully (even managing to sing a soft song before drawing her last breath). The head crumbles into tiny pieces and mixes with the sand.

Days later people return to Hiroshima. An old man who appeared in the beginning of the story discovers the body of the Jizo, finds another stone for his head and tells him how his wife and son died in the bombing. Thereafter, the new head takes on the same expression as the old one did when it had to watch the horribly burned little girl in her death throes. As time passes more and more people notice with amazement the transformation of the facial expression of the Jizō. His smile has not only disappeared but has been replaced by a scowl, and the kind look in his eyes has turned into a savage glare. A postscript informs the young readers that this statue of the Jizo still stands where it once stood . . in Hiroshima.

\section{Recent Developments}

In April, 1992 elementary school children throughout Japan began using the new kokugo textbooks written according to the guidelines issued by the Mombushō in 1987. The new 1992 Mitsumura Tosho textbooks (vol. 1, for the first semester; the second semester texts were not available at the time of this writing) bear the same titles and the same inspirational messages on the first pages as the 1989 edition. ${ }^{32}$ Many stories have been carried over from the previous Mitsumura Tosho series with minimal changes; for example, the new textbooks introduce 1,006 as opposed to 996 Chinese characters. Moreover, themes identified in previous kokugo textbooks are retained and reemphasized. Nature comes to the fore again,

${ }^{31}$ The Shitennō (Four Heavenly Kings) defended the four directions surrounding the Buddhist realm. The Heavenly Kings were originally gods of Indian folklore that were later amalgamated into the Buddhist pantheon. They have fierce, uncharacteristically Japanese, expressions, bear weapons and crush demons underfoot. Representative images of the Heavenly Kings are often found guarding entrances to temples and shrines.

32 The Mitsumura Tosho textbooks were selected for this most recent survey as well because they are the most widely used series in Japan. The titles of the first volumes of the 1992 set are Kazaguruma, "Pinwheel" (first grade); Tampopo, "Dandelion" (second grade); Wakaba, "Young Leaves" (third grade); Kagayaki, "Radiance" (fourth grade); Ginka, "Silver River" (the equivalent of the English, "Milky Way"; fifth grade); Sōzō, "Creation" (sixth grade). Size and format remain basically the same, although covers, photographs, illustrations and artwork have been redesigned; vol. 1 of each grade reader now contains 7 or 8 as opposed to 9 units; and the lengths of the books vary somewhat from that of the 1989 series. 
both in stories repeated from earlier editions (e.g. "Swamp Cabbages" and "The Wisdom of the Dandelion," to name two that were referred to earlier in this study) and in new stories. Attractive color photos of plants, seascapes, and landscapes grace the frontispiece of virtually every textbook in the new series. Animals, as opposed to people, figure in most of the stories, as before. ${ }^{33}$ Even a fantasy introducing the possibility of "other worlds" that operate according to different physical laws does so through the character of an animal: a whale that walks, talks, and eventually manages to fly ("The Day the Wind Is Strong," [Kaze ga tsuyoi hi], sixthgrade reader). People and animals care for each other in stories such as "The Rolling Riceball" ("Musubi Kororin," first-grade reader), in which a peasant gives rice to field mice and is rewarded with gold in turn. Even stories that would appear to be about people and their concerns turn out to center around subjects that are about nature or that evoke traditional responses to natural beauty. For example, a young boy's grandfather dies but remains with him in spirit through the beautiful blossoms of the grandfather's magnolia tree in "The School of Goodbye" ("Sayōnara no Gakkō," fifth-grade reader). A boy's favorite uncle, a magician who leaves Japan for parts unknown, communicates with him from afar through flowers in "Flowers and the Magician" ("Hana to Majutsushi," sixth-grade reader).

The poetical treatment of nature continues to figure prominently. In "The White Hat" ("Shiroi Boshi"), anthologized in both the 1989 and 1992 editions of the fourth-grade reader, magical transformations take place on a sunny afternoon in early summer, and "poetic logic" is exemplified in the delicate shifts of image to image (white shirt, summer orange, white cap, summer orange, white butterfly, summer orange, boy and mother with a butterfly net, girl, field, white flowers, white butterflies) that link its parts, as well as in the synesthesia of scent, color, and warmth. Each of the 1992 textbooks contains a section on poetry, as before, and there is once again a special feature article on classical tanka and haiku in the sixth-grade reader, with an emphasis on the longevity of these ancient, yet vital and flexible, Japanese poetic forms, which (in the case of tanka) have been practiced for over a thousand years.

Natural beauty, poetry, and the theme of the continuity of the Japanese "race" are conjoined in the frontispiece photograph of the "Jömon sugi" and the poem about the tree that appear in the fourth-grade reader. The cryptomeria tree in Kagoshima Prefecture, designated a natural treasure (tennen kinenbutsu) of the nation, is celebrated in a poem that asks children to compare their ages and the ages of their parents with the tree that stood (and still stands) for a thousand years - that is, "the equivalent of

\footnotetext{
${ }^{33}$ Roughly a third of the stories feature human characters; the rest are dominated by images of plants, animals, landscapes, and other natural features.
} 
7,200 years of human life." The message of the continuity of life on the Japanese islands is brought home audibly as well as visually, when children recite the poem aloud, imaginging that they themselves are the tree, as they are asked to do in the exercises following the text.

The collective experiences of the Yamato family continue to be emphasized in a variety of ways, including through references to the Pacific War, such as in Tsuboi Sakae's well-known story ("The Song of the Mortar" [Ishiusu no uta]) about the war orphan Chieko who survives the bombing of Hiroshima and pledges to work ever harder to secure a better future for her people. This story was in the 1989 sixth-grade reader and reappears in the 1992 edition, accompanied by updated illustrations.

Factual articles about features of life in the different regions of Japan (e.g., "The Snow Country Today" [Yukiguni wa ima], traditional Japanese folktales (e.g., "The Rolling Rice Ball" [Musubi kororin]), stories with traditional premodern rural settings (e.g., "The Story of Kitchomu" [Kitchomu banashi]), and stories set in country villages (e.g., "Crossing the Suspension Bridge" [Tsuribashi o Wataru]), as well as articles on Japan's remote past, seem to stress the importance of "wareware nihonjin": "we, the Japanese people." For example, "The Discovery of the Nagayaō Wood Strips" ("Nagayaō mokka no hakken"), a report of an archeological excavation that leads to the reconstruction of life on an eighth-century nobleman's estate in Nara, the country's first permanent capital, reminds sixth-graders of Japan's long and special history.

This concern with the preservation and promotion of a Japanese identity does not preclude in the 1992 series (as it did not in the 1989 series) reaching beyond Japanese borders. The theme of nature within Japan seems to lead perforce to worldwide concerns about the environment. In fact, mankind's existence on earth and the life of the planet are subjects treated in the fourth-, fifth-, and sixth-grade readers: in "Searching for Dinosaurs" (Kyōryū no saguru) and "Visiting an Incineration Plant" (Shōyaku kojō no kengaku) in the fourth-grade reader; "I Am Grass" (Ware wa kusa nari), "Treasuring Nature" (Shizen o taisetsu ni), "The World the Map Shows" (Chizu ga miseru sekai), "Continents Move" (Tairiku wa ugoku), "Flour and Life" (Kona to seikatsu), and two stories about nuclear arms in the fifth-grade reader; and "The Blessings of the Sun" (Taiyō no megumi) and "Ozone Destroyed," (Ozon kowareru) in the sixthgrade reader.

However, what might be called a more dramatic international dimension is brought to the fore in five stories translated from English and one story written on a Korean subject by a second-generation Korean author born in Japan. Three of these stories appear in the new third-grade reader: a translation of Anita Hewitt's "Kangaroo Joey Finds His Shadow" ("Kage o mitsuketa kangarū bōya"); a translation of "Elmer Meets the Tigers" 
("Eruma, tora ni au") from Ruth Stiles Gannett's book My Father's Dragon; and a re-creation in Japanese of the Korean folktale, "The Three Year Mountain Pass" ("Sannentoge") by Yi Kum Ok. The fourth-grade reader contains a translation of Eve Titus's story, Anatole, about a self-employed mouse named Anatole who works as a cheese taster in a French cheese factory. The British writer Allison Uttley's story, "The Cornfield" (translated into Japanese as "Mugibatake"), is the seventh foreign story and appears in the fifth-grade reader. Though only five in number, the new stories mark a significant increase for the first-semester third-, fourth-, and fifthgrade readers, in which previously there were none.

"The Three Year Mountain Pass" appears to be the first Korean story to ever appear in a kokugo textbook. It is set in a traditional Korean village and makes no reference to Koreans in Japan, but its presence nonetheless constitutes a minor landmark, given the long history of difficult relations between Japan and Korea and the highly controversial status of Koreans living in Japan. It is a fantastic but optimistic story that dramatizes the capacity to adopt a new point of view, to change. The legend of the "three year mountain pass," which is taken to mean that a person has but 3 years to live should he or she stumble and fall while going over a certain mountain pass, is reinterpreted by a young miller to mean that one will live for 3 more years if one stumbles once, for 6 more years if one should fall twice, 30 more years if one should fall ten times, and 300 more years if one falls a hundred times. The old villager in the story, who stumbles and falls and falls into a deep depression thinking that he will die within the next 3 years, is rejuvenated and revitalized by the young miller's ironic lesson. The message of change is impressed on the young readers through exercises following the story that urge children to repeatedly compared the old and new interpretations of the "three year pass."

The themes of challenge and change are ever present throughout the third-grade reader. The young kangaroo in "Kangaroo Sonny Finds a Shadow" is reluctant to leave the warm security of his mother's pouch but, led by the desire to "have" his own shadow, eventually leaves it to explore the world on his own two feet. This may also be read as an illustration of an urge to overcome the desire to be indulged and protected by a parent or other care giver (a psychological phenomenon common among young Japanese children, who are said to amaeru, to cling to their parents with the expectation of being indulged by them). ${ }^{34}$ This same reader also features a story about a third-grade boy who conquers his fear of heights and succeeds, howsoever timidly, in climbing a ladder at school. "Elmer Meets the Tigers" similarly conveys the message of rising

${ }^{34}$ See Takeo Doi's Anatomy of Dependence, trans. John Bester (Tokyo: Kodansha, 1973), for an extended analysis and discussion of the kinds of behavior associated with amaeru and its nominal form, amae, which he regards as characteristically Japanese. 
to meet challenges and emphasizes as well relying on self-confidence and inventive thinking to overcome unexpected difficulties. (Elmer, in the episode translated here, gives the tigers chewing gum and thus prevents them from exercising their teeth on him.) The science article at the end of the third-grade reader is entitled "Changing Colors of Soap Bubbles" and is followed by a short essay on "things that change."

That this textbook may have been designed with the aim of encouraging a more open attitude to change would seem to be borne out by the inclusion of the one story that has been carried over from the 1989 edition. In "Crossing the Suspension Bridge" ("Tsuribashi o wataru"), a city girl visiting a mountain village overcomes her fear and works up the courage to cross a suspension bridge spanning a ravine in order to play with the local children. Equally significant, it seems, is the fact that stories that have not been repeated are the ones that depict children in more passive, reflective moods, for example, "The Chair at the Beach" ("Hamabe no isu"), or that focus on the child as the passive recipient of another's child's kindness in a traditional rural setting, for example, "Tarō Cricket" ("Tarō kōrogi”).

A new interest in meeting challenges can also be seen in the story, "Anatole Goes to the Factory" in the fourth-grade reader. This story about the mouse who is not caught in a trap baited with cheese but instead wins accolades and wealth by serving as the discerning cheese taster of a cheese factory introduces a kind of energetic irony that is also new to the kokugo reader. ${ }^{35}$

If, at this point, we asked ourselves the question, How closely did the designers of the new textbooks follow Mr. Nakasone's recommendations? we could answer without hesitation, in part, Very closely. They do indeed promote the preservation and development of traditional Japanese values, as did the designers of the 1989 textbooks. They do, however, in addition, albeit to a considerably lesser degree, introduce the notion of "change" as a universal human experience and the need to develop some of the qualities required to successfully meet "change" and its attendant challenges - for example, self-confidence and inventive thinking. This may well be, although small and cautious, the most important step those designers have taken in the direction of the internationalization of the kokugo (national language) readers.

${ }^{35}$ One may, however, note that the French setting in the original American story has been deemphasized; characters in the Japanese version do not intersperse their speech with French words and phrases (ma chere, c'est la vie, magnifique, etc.), as they do in the English version. And Anatole is congratulated on winning the status not of a businessman, as in the original, but as a sarariman (a salaryman, someone who works for a company rather than a quasi-independent entrepreneur). 